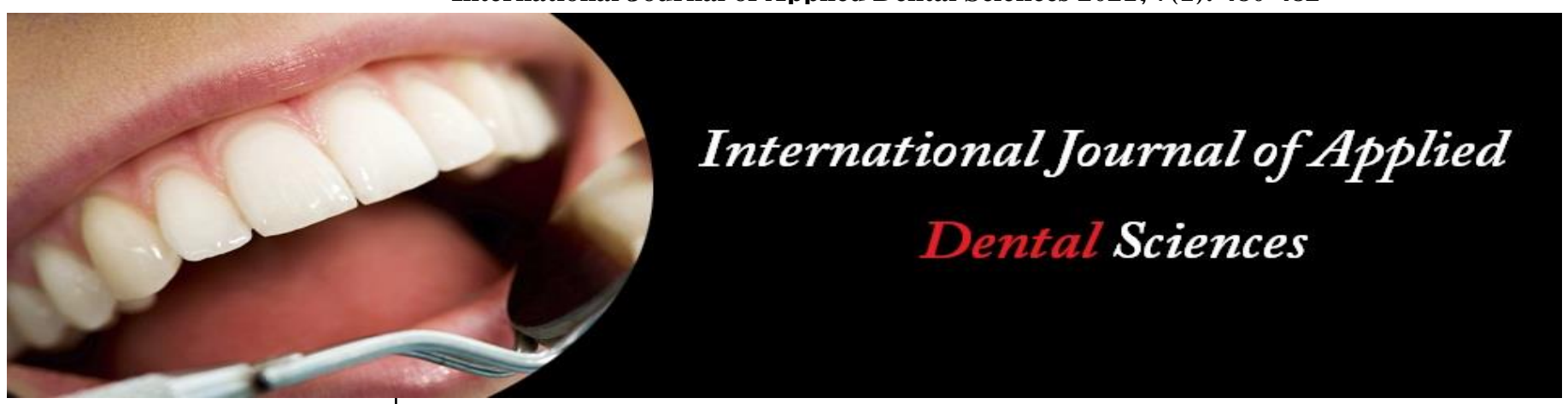

ISSN Print: 2394-7489

ISSN Online: 2394-7497

IJADS 2021; 7(1): 480-482

(C) 2021 IJADS

www.oraljournal.com

Received: 13-11-2020

Accepted: 15-12-2020

Karina Lizbeth Briceño-Cardona Ph.D. Student, Universidad

Autónoma de Nuevo León,

Facultad de Ciencias Biológicas,

Facultad de Odontología, Nuevo

León, CP66455, México

Claudio Cabral Romero

Doctor en Ciencias, Universidad

Autónoma de Nuevo León,

Facultad de Ciencias Biológicas,

Facultad de Odontología, Nuevo

León, CP66455, México

Rene Hernandez Delgadillo

Doctor en Ciencias, Universidad

Autónoma de Nuevo León,

Facultad de Ciencias Biológicas,

Facultad de Odontología, Nuevo

León, CP66455, México

Sergio Arturo Galindo-Rodríguez

Doctor en Ciencias, Universidad Autónoma de Nuevo León,

Facultad de Ciencias Biológicas,

Facultad de Odontología, Nuevo

León, CP66455, México

Juan Manuel Solís-Soto

Doctor en Ciencias, Universidad

Autónoma de Nuevo León,

Facultad de Ciencias Biológicas,

Facultad de Odontología, Nuevo

León, CP66455, México

Corresponding Author: Juan Manuel Solís-Soto

Doctor en Ciencias, Universidad

Autónoma de Nuevo León,

Facultad de Ciencias Biológicas,

Facultad de Odontología, Nuevo

León, CP66455, México

\section{Equisetum extracts are anti-inflammatory and antibacterial, an oral potential therapeutic agent}

\section{Karina Lizbeth Briceño-Cardona, Claudio Cabral Romero, Rene Hernandez Delgadillo, Sergio Arturo Galindo-Rodríguez and Juan Manuel Solís-Soto}

DOI: $\underline{\text { https://doi.org/10.22271/oral.2021.v7.i1g.1172 }}$

\section{Abstract}

Introduction: Due to its ability to prevent chromosomal damage, the genus Equisetum is likely to have an interesting field of potential use in clinical applications.

Objective: To analyze the literature on Equisetum, particularly its anti-inflammatory, antibacterial and cytotoxicity effects, from a dental approach. Methodology: In PubMed, Science Direct, Google Schoolar searched for information with combinations of the keywords: Equisetum, anti-inflammatory, antibacterial, and cytotoxicity.

Results: Equisetum possesses anti-inflammatory properties, inhibiting proinflammatory cytokine production and modulating $\mathrm{T}$ and $\mathrm{B}$ lymphocyte activity. It has antibacterial and antifungal effects against gram positive and gram negative bacteria, including $S$. mutans and Candida. Administered in controlled doses, toxicity with clinical signs is not detected, however, it shows antitumor effect.

Conclusion: Equisetum has anti-inflammatory and antibacterial properties and does not show cytotoxicity, it is a potential therapeutic agent for oral treatments.

Keywords: equisetum, anti-inflammatory, antibacterial, cytotoxicity

\section{Introduction}

Natural products are substances produced by a living organism in nature with biological activity, thanks to their secondary metabolites that include a wide category of compounds ${ }^{[1]}$. Since plants are the source of more than $25 \%$ of prescription and over-the-counter drugs, conventional medicine is becoming increasingly receptive to the use of plant-derived antimicrobials and other natural products. The increased use of herbal medicines has renewed interest in the effects of plant extracts to control plaque and other oral diseases ${ }^{[2]}$. Natural extracts have been shown to have a beneficial effect in the development of clinical therapies in the dental area, such is the case of Aloe vera which has been used for industrial, dental and wound healing applications ${ }^{[3]}$, patients use natural remedies to treat oral ailments ${ }^{[4]}$. S. mutans begins colonization of the mouth early in life and is responsible for the formation of mature biofilms, resulting in early childhood caries, plant extracts are effective in reducing the bacterial load ${ }^{[5]}$

On the other hand, ethanolic extract of Equisetum may serve as an alternative anticancer agent for the treatment of pancreatic carcinoma with no or minimal side effects to the patient [6]. Methanolic extract of Equisetum arvense inhibits diabetes-induced detrimental effects ${ }^{[7]}$. The methanolic crude extract has antimicrobial activity ${ }^{[8]}$.

Currently there is no review in the literature about the benefits of species of Equisteum genus from the odontological point of view, so in this work we analyze the literature on this subject, particularly its anti-inflammatory, antibacterial and cytotoxic effects, from an odontological point of view.

\section{Material and Methods}

Articles on the subject published through the PubMed, Scopus and Google Scholar databases were analyzed, with emphasis on the last 5 years. 
The quality of the articles was evaluated using PRISMA guidelines, i.e., identification, review, choice and inclusion. The quality of the reviews was assessed using the measurement tool for evaluating systematic reviews (AMSTAR-2) ${ }^{[9]}$.

The search was performed using Boolean logical operators AND, OR and NOT.

It was performed with the words "Equisetum " in combination with "anti-inflammatory", "antibacterial" and "cytotoxicity". The keywords were used individually, as well as each of them related to each other.

Initially, the titles of all the articles were selected, the abstract of each one was evaluated and the articles were chosen for a complete reading review.

\section{Results \& Discussion}

\subsection{Anti-inflammatory effects}

A variety of works have reported and demonstrated the antiinflammatory effect of various species of Equisetum. It accelerates wound healing and decreases pain, perhaps due to the presence of phenolic compounds and flavonoids [10-14]. The extract inhibits lymphocyte activation, decreasing the expression of CD69 and IL-2 receptors, thereby inhibiting IL2 production, in addition it reduces the production of IFNgma and TNF-alpha ${ }^{[15]}$. Similarly, it inhibits the production of IL- ${ }^{[16,17]}$. It has an immunomodulatory effect on T and B lymphocytes ${ }^{18}$.

Equisetum arvense extract inhibits the production of TNFalpha, a proinflammatory cytosine, induced by LPS from Aggregatibacter actinomycetemcomitans ${ }^{[19]}$.

The use of Equisetum extracts in hydrogel as an antiinflammatory agent has been recommended ${ }^{[20]}$.

\subsection{Antibacterial effect}

Equisetum has antibacterial effects on gram-positive cocci ${ }^{[16}$, 21, 22], and antifungal effect ${ }^{[23]}$. In addition, it inhibits the growth of S aureus grown on hydroxyapatite or in culture ${ }^{\text {[24- }}$ 25]. In conjunction with silver nanoparticles its antibacterial capacity is increased ${ }^{[26]}$.

There are also reports that it presents antiviral effect against herpes simplex virus type 2, prevents entry into cells ${ }^{[27]}$.

Equisteum extracts added to denture adhesives prevent Candida growth and anti-biofilm capacity ${ }^{[25,28-30]}$. Similarly, they prevent the growth of Streptococcus mutans ${ }^{[25]}$.

\subsection{Cytotoxicity}

Equisetum extracts do not exhibit cytotoxicity in contact with human cells, these properties could qualify E. giganteum extract as a promising alternative for the treatment and prevention of oral candidiasis and prosthetic stomatitis ${ }^{30}$. They have even demonstrated protective effects on liver and gastric mucosa ${ }^{[31-33]}$.

Equisteum can also be toxic, depending on the dose, due to its alkaloid content ${ }^{[34-35]}$. It has compounds that can affect the action of Adenosine deaminase ${ }^{[36]}$. In conjunction with silver nanoparticles it presents strong toxic effect against HepG2 cell lines ${ }^{[26]}$. It is even independently toxic against breast, lung, cervix and liver cell lines ${ }^{[35,37-38]}$.

\section{Conclusions}

The species of the genus Equisteum are definitely a line to be investigated in the dental area, since they have demonstrated anti-inflammatory and antibacterial effects without real cytotoxic effect, in addition, they have other positive effects as antioxidants and antinociceptive effects.

\section{References}

1. Teodor ED, Moroeanu V, Radu GL. Lignans from medicinal plants and their anticancer effect. Mini Rev Med Chem 2020:20(12):1083-1090.

2. Chinsembu, KC. Plants and other natural products used in the management of oral infections and improvement of oral health. Acta Trop 2016:154:6-18.

3. Jia L, Han N, Du J, Guo L, Luo Z. y Liu Y. Pathogenesis of Important Virulence Factors of Porphyromonas gingivalis via Toll-Like Receptors. Front Cell Infect Microbiol 2019:18; 9:262.

4. Dar-Odeh NS, Gasim RA, Binsaad SM, Abu-Hammad S, Abu-Hammad OA. Use of natural remedies to treat oral diseases among female patients in Al Madinah, western Saudi Arabia. J Complement Integr Med 2019: 16(3):19:/j/jcim.2019.16.issue-3/jcim-2018-0032/jcim2018-0032.xml.

5. Valadas L, Gurgel MF, Mororó JM, Fonseca S, Fonteles $\mathrm{C}$, de Carvalho $\mathrm{C}$ et al. Dose-response evaluation of a copaiba-containing varnish against streptococcus mutans in vivo. Saudi Pharm J 2019:27(3):363-367.

6. Bhat AA, Ahama B, Rehman MU, Ahmad P. Impact of ethanolic extract of Equisetum arvense (EA1) on pancreatic carcinoma AsPC-1 cells. Saudi J Biol Sci 2020:27(5):1260-1264.

7. Fajri M, Ahmadi A, Sadrkhanlou R. Protective effects of Equisetum arvense methanolic extract on sperm characteristics and in vitro fertilization potential in experimental diabetic mice: An experimental study. Int $\mathbf{J}$ Reprod Biomed 2020:27;18(2):93-104.

8. Dos Santos Alves CF, Bonez PC, de Souza MdE, da Cruz RC, Boligon AA, Piana $\mathrm{M}$ et al. Antimicrobial, antitrypanosomal and antibiofilm activity of Equisetum hyemale. Microb Pathog 2016:101:119-125.

9. Shea BJ, Reeves BC, Wells G, Thuku M, Hamel C, Moran J et al. AMSTAR 2: a critical appraisal tool for systematic reviews that include randomised or nonrandomised studies of healthcare interventions, or both. BMJ. 2017;358:j4008.

10. Asgharikhatooni A, Bani S, Hasanpoor S, Mohammad Alizade S, Javadzadeh Y. The effect of Equisetum arvense (horse tail) ointment on wound healing and pain intensity after episiotomy: a randomized placebocontrolled trial. Iran Red Crescent Med J 2015;17(3):31.

11. Carmignan F, Matias R, Carollo CA, Dourado DM, Fermiano MH, Silva BAK et al. Efficacy of application of Equisetum pyramidale Goldm. hydrogel for tissue restoration of induced skin lesions in Wistar rats. Braz $\mathbf{J}$ Biol 2020:80(1):12-22.

12. Ozay Y, Kasim Cayci M, Guzel-Ozay S, Cimbiz A, Gurlek-Olgun E, et al. Effects of Equisetum arvense Ointment on Diabetic Wound Healing in Rats. Wounds. 2013:25(9):234-41.

13. Do Monte FH, dos Santos JG Jr, Russi M, Lanziotti VM, Leal LK, Cunha GM. Antinociceptive and antiinflammatory properties of the hydroalcoholic extract of stems from Equisetum arvense L. in mice. Pharmacol Res. 2004:49(3):239-43.

14. Kalluri JR, West J, Akkaraju GR, Canham LT, Coffer JL. Plant-Derived Tandem Drug/Mesoporous Silicon Microcarrier Structures for Anti-Inflammatory Therapy. ACS Omega. 2019:9;4(5):8359-8364.

15. Gründemann C, Lengen K, Sauer B, Garcia-Käufer M, Zehl M, Huber R. Equisetum arvense (common horsetail) modulates the function of inflammatory 
immunocompetent cells. BMC Complement Altern Med. 2014;14:283.

16. Pallag A, Filip GA, Olteanu D, Clichici S, Baldea I, Jurca $\mathrm{T}$ et al. Equisetum arvense L. Extract Induces Antibacterial Activity and Modulates Oxidative Stress, Inflammation, and Apoptosis in Endothelial Vascular Cells Exposed to Hyperosmotic Stress. Oxid Med Cell Longey. 2018:14;2018:3060525.

17. Chaiyana W, Punyoyai C, Somwongin S, Leelapornpisid $\mathrm{P}$, Ingkaninan $\mathrm{K}$, Waranuch $\mathrm{N}$ et al. Inhibition of $5 \alpha-$ Reductase, IL-6 Secretion, and Oxidation Process of Equisetum debile Roxb. ex Vaucher Extract as Functional Food and Nutraceuticals Ingredients. Nutrients 2017:10;9(10):1105.

18. Farinon M, Lora PS, Francescato LN, Bassani VL, Henriques AT, Xavier RM et al. Effect of Aqueous Extract of Giant Horsetail (Equisetum giganteum L.) in Antigen-Induced Arthritis. Open Rheumatol J 2013:30;7:129-33.

19. Shiba F, Miyauchi M, Chea C, Furusho H, Iwasaki S, Shimizu R, et al. Anti-inflammatory effect of glycyrrhizin with Equisetum arvense extract. Odontology. 2020 Nov 3. https://doi.org/10.1007/s10266020-00563-3.

20. Kołodziejska J, Berner-Strzelczyk A, Piechota-Urbańska M. Suche ekstrakty roślinne $\mathrm{w}$ recepturze hydrozeli stomatologicznych z Carbopolem 971P [Dry plant extracts in the prescription of dental hydrogels with Carbopol 971P]. Polim Med. 2009;39(3):27-35.

21. Ferrazzano GF, Roberto L, Catania MR, Chiaviello A, De Natale A, Roscetto E et al. Screening and Scoring of Antimicrobial and Biological Activities of Italian Vulnerary Plants against Major Oral Pathogenic Bacteria. Evid Based Complement Alternat Med 2013, 316280.

22. Radojevic ID, Stankovic MS, Stefanovic OD, Topuzovic MD, Comic LR, Ostojic AM. Great horsetail (Equisetum telmateia Ehrh.): Active substances content and biological effects. EXCLI J. 2012:24;11:59-67. eCollection 2012.

23. De Queiroz GM, Politi FA, Rodrigues ER, SouzaMoreira TM, Moreira RR, Cardoso CR et al. Phytochemical Characterization, Antimicrobial Activity, and Antioxidant Potential of Equisetum hyemale L. (Equisetaceae) Extracts. J Med Food. 2015:18(7):830-4.

24. Bessa Pereira C, Gomes PS, Costa-Rodrigues J, Almeida Palmas R, Vieira L, Ferraz MP et al. Equisetum arvense hydromethanolic extracts in bone tissue regeneration: in vitro osteoblastic modulation and antibacterial activity. Cell Prolif 2012;45(4):386-96.

25. de Oliveira JR, de Castro VC, das Graças Figueiredo Vilela P, Camargo SE, Carvalho CA, Jorge AO et al. Cytotoxicity of Brazilian plant extracts against oral microorganisms of interest to dentistry. BMC Complement Altern Med 2013;13:208.

26. Das G, Patra JK, Shin HS. Biosynthesis, and potential effect of fern mediated biocompatible silver nanoparticles by cytotoxicity, antidiabetic, antioxidant and antibacterial, studies. Mater Sci Eng C Mater Biol Appl 2020;114:111011.

27. Churqui MP, Lind L, Thörn K, Svensson A, Savolainen $\mathrm{O}$, Aranda $\mathrm{KT}$ et al. Extracts of Equisetum giganteum L and Copaifera reticulate Ducke show strong antiviral activity against the sexually transmitted pathogen herpes simplex virus type 2. J Ethnopharmacol 2018;210:192197.
28. Almeida NLM, Saldanha LL, da Silva RA, Pinke KH, da Costa EF, Porto VC et al. Antimicrobial activity of denture adhesive associated with Equisetum giganteumand Punica granatum-enriched fractions against Candida albicans biofilms on acrylic resin surfaces. Biofouling 2018:34(1):62-73.

29. Da Silva RA, Bernardo LP, Moreno JML, Lara VS, Porto VC. Equisetum giganteum influences the ability of Candida albicans in forming biofilms over the denture acrylic resin surface. Pharm Biol. 2017:55(1):1698-1702.

30. Alavarce RA, Saldanha LL, Almeida NL, Porto VC, Dokkedal AL, Lara VS. The Beneficial Effect of Equisetum giganteum L. against Candida Biofilm Formation: New Approaches to Denture Stomatitis. Evid Based Complement Alternat Med. 2015:939625.

31. Jin M, Zhang C, Zheng T, Yao D, Shen L, Luo J et al. A new phenyl glycoside from the aerial parts of Equisetum hyemale. Nat Prod Res 2014;28(21):18138.

32. Yesilada E, Gurbuz I. Evaluation of the antiulcerogenic activity profile of a flavonol diglucoside from Equisetum palustre L. J Ethnopharmacol 2010:19;131(1):17-21.

33. Oh H, Kim DH, Cho JH, Kim YC. Hepatoprotective and free radical scavenging activities of phenolic petrosins and flavonoids isolated from Equisetum arvense. J Ethnopharmacol. 2004:95(2-3):421-4.

34. Cortinovis C, Caloni F. Alkaloid-Containing Plants Poisonous to Cattle and Horses in Europe. Toxins (Basel) 2015:8;7(12):5301-7.

35. Jabeur I, Martins N, Barros L, Calhelha RC, Vaz J, Achour L et al. Contribution of the phenolic composition to the antioxidant, anti-inflammatory and antitumor potential of Equisetum giganteum L. and Tilia platyphyllos Scop. Food Funct. 2017;8(3):975-984.

36. Zhang XG, Liu JW, Tang P, Liu ZY, Guo GJ, Sun QY et al. Identification of a New Uncompetitive Inhibitor of Adenosine Deaminase from Endophyte Aspergillus niger sp. Curr Microbiol 2018;75(5):565-573.

37. Al Mohammed HI, Paray BA, Rather IA. Anticancer activity of EA1 extracted from Equisetum arvense. Pak J Pharm Sci. 2017:30(5(Supplementary)):1947-1950.

38. Xu YM, Arnold AE, U Ren JM, Xuan LJ, Wang WQ, Gunatilaka AAL. Teratopyrones A-C, Dimeric Naphtho$\gamma$-Pyrones and Other Metabolites from Teratosphaeria sp. AK1128, a Fungal Endophyte of Equisetum arvense. Molecules 2020;25(21):5058. 